\title{
Social Security Versus Private Saving and Insurance
}

\author{
by George M. von Furstenberg *
}

\section{The demand for social provlsion for old age}

With the breakdown of extended families into nuclear units, children have increasingly ceased to support their parents directly in old age. In the absence of government income maintenance programs, individuals would therefore have to save enough during their working years to protect themselves against any abrupt reduction in their living standards after retirement and to provide for their dependent survivors. If individuals can reasonably prognosticate their future stream of earnings, future returns on their accumulated savings, future bequests and obligations to dependents, as well as their state of health, retirement, and time of death, they can (implicitly) solve a calculus of variations problem and determine how much they must save each year to maximize expected lifetime utility. The calculation requires individuals to consult their present as well as their future time preference rates so that their present as well as their future tastes for present versus future consumption are assumed to be known in addition to all the other elements identified above.

Unfortunately some individuals calculate poorly and the plans of others, no matter how finely spun, are upset by external events such as unforeseen medical expenditure, unemployment, forced retirement, not to speak of ruinous taxation, inflation, or war. Furthermore, even if individuals had suffered no such unexpected adversities so that they could very well have provided for old age on their own, the spectacle of elderly persons living in poverty relative to the living standards they had maintained during their working years is socially objectionable to many non-elderly persons, regardless of its cause. Hence, in democratic societies, governments have increasingly taken over the function of guaranteeing an acceptable standard of living for the elderly. They do so by providing no less than a cultural minimum of support for all (through demogrants, social security benefit minima, or on a means-tested basis) and by supplementing this socially determined minimum level of support through earnings-related pensions for most.

\section{The policy Issue}

While very few question society's obligation to alleviate dire indigence among the aged irrespective of cause, the government's growing role in providing a second tier of earnings-related pensions above the minimum has increasingly been challenged.

* Professor of Economics, Indiana University, Bloomington, U.S.A., and director of the Project on Capital Investment and Saving, sponsored by the American Council of Life Insurance, Washingtion, D.C. 
Some of these challengers are described and scrutinized in this paper. Thereafter, the rebuttal that is based on the alleged equivalence of government debt and taxes is presented and criticized. 1

Since private insurance companies are supervised and regulated by government agencies in most countries and since company and trade union pension schemes are increasingly covered by government guarantees and formal or de facto reinsurance, they are becoming just as secure as the pensions promised by the government. Admittedly, in countries like the United States, in which the indexing of private annuities and pensions to the cost of living is as yet rare, government programs may provide superior protection against inflation. On the other hand, future social security benefits are subject to modification by government policy and may thus be " recontracted." All considered, it is therefore far from clear that the real value of future pension benefits is more predictable and reliable in the public than in the regulated private insurance sectors of the economy.

Given the uncertain advantage of public programs in this regard, there are clear disadvantages to such programs in other respects which may tip the scales against the public provision of earnings-related pensions. These disadvantages arise from deleterious effects of pay-as-you-go financed social security programs on the supply of national saving. In the postwar economic environment in which the Keynesian "paradox of thrift" appears to have dissolved, the supply of national saving, rather than the strength of aggregate demand, is the blade that cuts. It determines capital formation and the level of output and real incomes, at least in the long run.

Social insurance wealth is the difference between the value of the future benefits to be derived from a particular retirement income program and the value of the stream of personal contributions yet to be made to that program, both discounted to the present at some realistic rate of interest. Since private pension wealth would be measured precisely in the same fashion, the very existence of social security wealth implies a reduction of private saving if the latter type of wealth is a good substitute for the former in household portfolios. However, if the government increases its surplus or reduces the budget deficit it would otherwise run so as to fund its deferred pension liabilities, as the governments of Canada and Sweden attempt to do in part, the increase in government-sector saving would offset some of the decline in private saving.

Most postindustrial countries do not have such offsets. Rather they are on a payas-you-go financing system, and any pay-as-you-go increase in current social security benefits and contributions does not change the government surplus or deficit, but it does create or add to a form of retirement wealth which is a close substitute for life insurance, private pensions, and other forms of providing for old age and survivors. Since life insurance companies and private pension funds, unlike the government, do not dissave the contributions or premiums currently received, but use them to fund the increase in future pension liabilities on an actuarially sound basis, they do not dissipate personal saving in the form of insurance contributions or premium payments

1 For detailed development of the major theoretical points and for econometric studies of the social security savings problem in specific countries the reader may want to consult the three volumes sponsored by the American Council of Life Insurance referenced in back. A survey of the pre-1977 literature is contained in the last reference provided there [4]. 
while the government does. It is this act of dissipation that makes government-created insurance wealth detract from national saving and a source of mounting concern in several countries, particularly the United States.

\section{Is government debt equivalent to taxes ? ${ }^{2}$}

Pay-as-you-go financing of government pension programs is possible because these programs are compulsory. Under this system the government requires employers and employees to make specific social security contributions in an amount roughly equal to the current benefits paid out or uses general revenue financing as a supplementary source of funds. In either case, governments with unbridled taxing and borrowing power can be expected to honor their deferred liabilities without current set-asides. Free from the requirement to fund their pension liabilities actuarially through the accumulation of budgetary reserves, governments are thus in a position to create individual private wealth by fiat.

If a person close to retirement is promised increased retirement benefits, he rightly considers his personal wealth to have risen and he may increase his spending accordingly. In so doing, however, he makes plain to younger members of the workforce and to future generations that the increased retirement wealth, while real enough for him, is fictitious for society as a whole. Thus government debt, whether evidenced by Treasury bills, notes, or bonds, or implied by deferred pension liabilities, does have a cost after all : it " taxes" heirs or descendants even though it substitutes for increased taxes on those currently living or for reductions in current government expenditures, including social security benefits.

Mindful of such negative consequences for their heirs, some of those whom growing social security wealth has enabled to increase their lifetime consumption may refuse to take advantage of this opportunity to benefit themselves at the expense of later generations. Rather, they may provide an extra bequest that will precisely compensate all future generations for the difference between the retirement income the current generation would receive from private saving and the greater retirement income they actually obtain from social security for the same sacrifice in preretirement income in the form of pension contributions or taxes. If such altruism were universal, individuals would pierce the government veil and destroy the government's ability to generate wealth effects and to induce additional consumption by issuing debt in lieu of taxes. Rather, they would consider themselves taxed just as surely by government debt as by taxes used to finance government expenditures. In words reminiscent of the Modigliani-Miller theorem in corporate finance, only the size of government expenditures would influence private behavior and it would do so irrespective of the form of financing.

Some U.S. economists have treated this - to us rather remote - possibility of the equivalence of government debt and taxes as axiomatic and promoted it to the level of virtual certainty. They argue, in effect, that anyone who leaves bequests will offset the government's attempts to redistribute consumption from future generations to the present generation because such government actions constitute unwanted inter-

2 In the United States, Robert Barro is the principal proponent of equivalence. For references see [4]. 
ference with his plans. Potential donors always have it within their power to reduce their planned gifts. However, once they have all determined that the optimal size of their bequests is positive, they will surely not appreciate the government's arranging for reverse gifts from young to old through unfunded social security programs. If provision for the standard of living of future generations motivated the bequests in the first place, the donors would not let the government diminish the size of their net oequest through such devices.

\section{Critique of the "Equivalence Theorem" 3}

While this equivalence theorem follows logically from its assumptions, some of its sweeping premises are overextended and some of the behavioral assumptions are unlikely to be universally applicable. Hence, as a practical matter, the equivalence theorem may not hold for the bulk of the population nor can it be used to assuage our qualms about the savings-reduced effects of unfunded social security programs.

In the United States at least, almost 80 percent of heads of U.S. households aged 65 and over reported in a 1962 sample survey that they had received no material inheritances during their lifetime. Parents in the middle or lower middle of the U.S. income distribution, who receive the bulk of their income in the form of earnings covered by social security taxes, make large gifts to their children by rearing them and having them educated with far less government support than is customary in other advanced countries. Such parents may not be inclined to heap tangible bequests on their offspring as well nor may they care to hold their issue harmless for governmentimposed transfers from young to old. Benevolence towards one's offspring does not have to be so extreme as to make the marginal utility to the parents of additional consumption by descendants exceed that of own consumption. Particularly if the descendants can be expected to support themselves at a permanent income level at least as high as that of their parents, many parents may feel they have done more than enough even without leaving tangible bequests (in forms other than human capital). Consequently such parents would be quite content to accept gifts from the young to the old arranged via the government's social security programs without wanting to return them. They may welcome the chance to make the young contribute to the retirement consumption of the old now that the extended three-generational family, in which such transfers would normally have been made privately, has tended to disintegrate.

With such a large fraction of the population at the corner solution of no bequests, the equivalence theorem is unlikely to hold wide sway; and there are still other considerations relating to the preferences of donors that cast doubt on its generality. Do people care about the future consumption of only their lineal descendants or do they care about the consumption of future generations in the abstract? If providing for one's offspring is the chief motivation, then all those who have no lineal descendants, or all those whose identification with the welfare of their descendants has been diluted through successive divorces and remarriages would have little reason to offset the government-arranged redistribution from young to old through private actions.

3 Many of the arguments developed here have been anticipated by Martin Feldstein, James Tobin, and Willem Buiter. See the contributions by Buiter and Tobin in [1]. 
True, even some childless individuals leave bequests, but this fact is more likely to be due to the surprise of death or the unwillingness of many to dissave all of their net assets by a certain age not knowing when they will die. Technically, individuals can " succeed" in leaving no bequests and still ensure their living standards until their uncertain time of death by converting all their net assets into annuity contracts, but few actually do so. Thus the existence of positive bequests does not necessarily prove altruism. Rather bequests may, in part, be a residual that an individual would have been quite willing to draw on if he had faced more extended illness or lived longer than he actually did.

Finally, even if bequests are chiefly intended for the welfare of heirs rather than a contingency reserve left over, it is not clear whether the concern for one's heirs relates to their future consumption or to passing on specific objects and stations, such as heirlooms, farms, businesses, or positions and practices that have traditionally been owned by a family. A simple cash or real-purchasing-power calculus is unlikely to underlie all of estate planning. Full private offset of fiscal actions can thus be deduced for the subgroup of altruistic donors who wish to leave positive bequests to lineal descendants only if their estate motivation is based on a cash-equivalent net of fiscal residuals. In fact, however, many donors are bent on providing a stake more imbued with their desire for dynastic continuity in a specific setting than with naked cash values for their heirs.

\section{Conclusion}

For all these reasons, the rediscovery of the equivalence theorem, first stated by David Ricardo in 1817, must be rejected as an adequate basis for policy, just as Ricardo had denied its applicability to the real world. Correspondingly, the concern with the adverse consequences of unfunded social insurance wealth for the supply of national saving, capital intensity, and living standards remains well founded.

If, as a practical matter, public pension and social security programs will never be funded actuarially in the United States and most other postindustrial countries, then government-supervised substitution of private for public retirement plans is the only way to achieve at least partial funding. If such substitution follows the British model of allowing employers to contract out of the earnings-related part of the state scheme if equivalent pensions are provided by the company plan, payroll taxes and social security wealth decline so as to reduce their adverse impact on capital formation.4

4 Throughout this paper we have ignored Feldstein's point that social security may have encouraged earlier retirement because government benefits are reduced in some countries if people continue to work past pension age. Such offsets are not used in either Canada, Great Britain, or Sweden, and the degree of offset has been reduced even in the United States through the 1977 amendments to the Social Security Act. Normally, the certain prospect of earlier retirement would cause people to save more and, possibly, to work longer hours while they are still working since they must sustain themselves for a longer period in retirement. However, once uncertainty of lifetimes and worktimes is admitted into a life-cycle model, it is not clear that the steady-state supply of savings and the stock of capital will, in fact, be increased by earlier retirement. For a demonstration see the editorial introduction to [1]. 
The detailed examination and possible adoption of this type of model may be recommended to countries like the United States in which political concern with insufficient saving and capital formation has mounted in the last few years.

\section{REFERENCES}

1. VON FURSTENBERG, George M., ed. Social Security versus Private Saving in Postindustrial Democracies. Sponsored by the American Council of Life Insurance (ACLI). Cambridge, Mass. : Ballinger, forthcoming.

2. - The Government and Capital Formation. ACLI, forthcoming.

3. - Capital, Efficiency and Growth. ACLI, forthcoming.

4. - and MALKIEL, Burton G. "The Government and Capital Formation, A Survey of Recent Issues," Journal of Economic Literature, Sept. 1977, Vol. 15, No. 3, pp. 835-878. 